\title{
QUALITY EVALUATION OF COOKIES PRODUCED FROM WHEAT AND BARLEY FLOUR
}

\author{
Gjore Nakov \\ Branch Razgrad, University of Ruse „Angel Kanchev“, Bulgaria \\ Aprilsko vastanie 47, 7200 Razgrad, Bulgaria \\ e-mail: gnakov@uni-ruse.bg
}

\begin{abstract}
Functional foods are foods enriched with nutritional supplements that have a positive effect on the physiological state of the human body. Cookies belong to the group of confectionery products and are more precisely dried confectionery products, characterized by an appealing appearance, pleasant aroma and taste. Barley (Hordeum vulgare) is an important cereal grain. Barley flour has a moderate flavour, light walnut taste and contains a large amount of thiamine (vitamin B1) and phosphorus. The aim of this study is to investigate physical properties of cookies with different amounts of barley flour (30,50, 70 and 100\%). The results showed, that by increasing the amount of added barley flour to the recipe content, baking loss, width and thickness of cookies increase as well. Keywords: cookies, barley, functional foods.
\end{abstract}

\section{INTRODUCITON}

Cereals are main human food and they are a vital source of energy [3, 5, 6]. The modern eating habits, the real trend in the production and consumption of cereals, have a healthy, ecological and social influence. The European Union fights various diseases, typical for the modern world - obesity, osteoporosis, cancer, diabetes, allergies and dental problems. The developing countries also face difficulties in dealing with aging of the population, high energy food consumption and unbalanced diets [2]. Although wheat is considered a good source of energy and other nutrients, it has a low nutritional value. Proteins in cereals are deficient in the essential amino acids lysine and threonine. Because of that, the exchange (completely or partially) of wheat with healthier cereal grains helps improve the nutritional value of wheat products [8].

Barley gains belong to the Poaceae family, Triticeae and Hordeum genus. Globally, Hordeum vulgare is grown. Barley is a cereal grain, which has been used for bread production since the Neolithic [10]. Barley flour is often used as a partial substitute of wheat flour in the production of cereal-based products due to high levels of $\beta$-glucans, lignans, phenolic compounds and many essential vitamins and minerals [4].

Cookie production is considered quite substantial part of food industry, due to the fact that cookies have high nutritional value, especially when their ingredients are rich in fats and proteins [7,9].

The aim of this article is to investigate the quality of the cookies produced with partial or total exchange of wheat flour with barley flour. 


\section{IRTITIE}

Ipplied Researrches in Technics, Technologies and Educiation

Journal of the Faculty of Technics and Technologies, Trakia University https://sites.google.com/a/trakia-uni.bg/artte/

\section{MATERIAL AND METHODS}

\subsection{Material}

Wheat plain white flour (Mill Popovo, Bulgaria) and barley flour (Ekosem Bulgaria OOD) were used in this research. The rest of the raw materials: sucrose (Agrana Bulgaria); glucose solution - $\mathrm{D}(+)$ - glucose monohidrat (Himiteks OOD Dimitrovgrad, Bulgaria); butter (Verea, Bulgaria); sodium bicarbonate $\left(\mathrm{NaHCO}_{3}\right.$, Radikom, Bulgaria); sodium chloride ( $\mathrm{NaCl}$, Global Food) were obtained from local shops in Razgrad.

\subsection{Methods}

\subsubsection{Production of cookies}

Cookies were produced according to AACC Approved Method 10-50D [1] prepared in a laboratory at the University of Ruse "Angel Kanchev" - branch Razgrad (Bulgaria). from composite flours containing plain white flour and barley flour in ratios 100:0, 70:30, 50:50, $30: 70$ and $0: 100$ respectively.

\subsubsection{Physical characteristics of cookies}

Cookie volume and baking quality of cookie composite flour was determined according to AACC Approved Method 10-50D [1]. Six biscuits were laid edge to edge, and the total width was measured. Then, the biscuits were rearranged by rotating them $90^{\circ}$, the width was measured again, and the average width was calculated. To get an average thickness, six cookies were stacked on top of one another and measured, as well as after restacking them in a different order. The width and thickness of six cookies were divided by six to obtain $\mathrm{W}$ (cm) and $T(\mathrm{~cm})$. Spread factor was calculated as $W / T$ multiplied by 10 . This test was repeated for each of the three different batches.

Colour was estimated with the use of chromameter Konica Minolta CR-400 and expressed as CIE $L^{*} a^{*} b^{*}$ coordinates $\left(L^{*}\right.$ is the luminance or lightness component, which ranges from black $(L=0)$ to white $(L=100)$, and parameters $a^{*}$ (from green to red) and $b^{*}$ (from blue to yellow) are the two chromatic components, which range from - 128 to 127 and the total colour difference $(\Delta E)$ was calculated according to CIE76 colour difference equation (1):

$$
\Delta E=\sqrt{\left(L-L_{0}\right)^{2}+\left(b-b_{0}\right)^{2}+\left(a-a_{0}\right)^{2}}
$$

where $L_{0}{ }^{*}, a_{0}{ }^{*}$ and $b_{0}{ }^{*}$ correspond to dough of samples, and $L^{*}, a^{*}$ and $b^{*}$ to produced samples. All data were presented as mean values of at least three replicates from each batch.

\subsubsection{Statistical analysis}

Analysis of variance (ANOVA) and Fisher's Least Significant Difference test (LSD) at $p<0.05$ were performed with the software XLSTAT 2017 and Microsoft Office Excel 2013. 


\section{RESULTS AND DISCUSSION}

In the last 10 years, the innovations in cookie production have been oriented towards obtaining cookies with low content of sugars, substitution of sugars with other sweeteners, use of fats with various characteristics, as well as enrichment of cookies with supplements possessing functional qualities [7]. In Figure 1 is shown the cooking loss after baking the cookies.

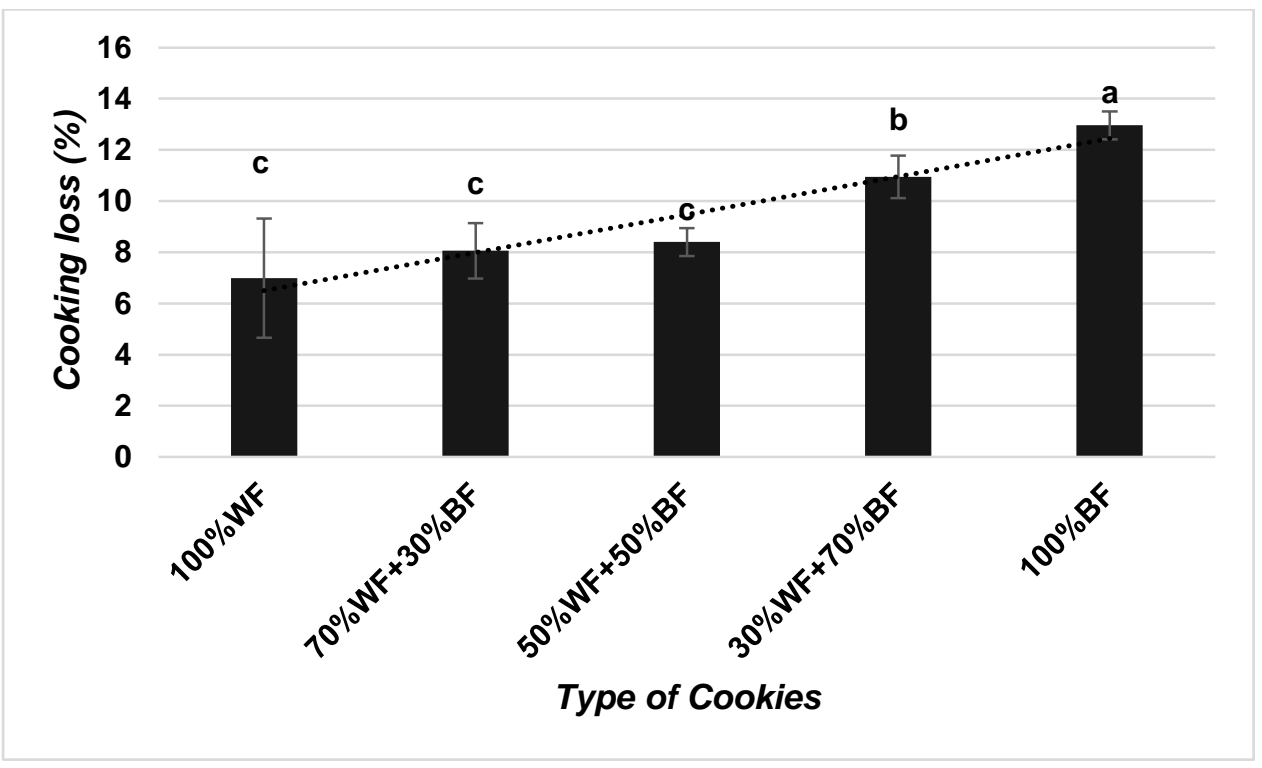

Figure 1. Cooking loss in cookies ${ }^{* / * *}$

${ }^{*} W F-$ White Flour; BF - Barley Flour. ${ }^{*}$ Values are means $\pm S D(n \geq 3)$; Values with different superscripts $(a-c)$ are significantly different $(p<0.05)$

The lowest rate of cooking loss has been determined in the sample cookies $(6.99 \pm 2.33 \%)$, and the highest - in the cookies containing $100 \%$ barley flour $(12.96 \pm 0.55 \%)$. The statistics states that when in the content of the cookies $70 \%$ and more of barley flour is included, the baking loss is statistically significant. Table 1 shows the phisical properties of the cookies (volume, width, thickness and spread factor).

Table 1. Physical properties of cookies*

\begin{tabular}{|c|c|c|c|c|}
\hline Type of cookies & Volume $\left(\mathrm{cm}^{3}\right)$ & Width $(\mathrm{cm})$ & Thickness $(\mathrm{cm})$ & $\begin{array}{c}\text { Spread } \\
\text { factor }(\mathrm{W} / \mathrm{T} x \\
10)\end{array}$ \\
\hline $100 \% W F$ & $7.89 \pm 1.54$ & $5.33 \pm 0.41$ & $1.05 \pm 0.05$ & 50.76 \\
\hline $70 \% \mathrm{WF}+30 \% \mathrm{BF}$ & $24.89 \pm 0.77$ & $5.61 \pm 0.22$ & $1.92 \pm 0.27$ & 29.21 \\
\hline $50 \% \mathrm{WF}+50 \% \mathrm{BF}$ & $24.22 \pm 1.02$ & $5.67 \pm 0.20$ & $2.35 \pm 0.20$ & 24.13 \\
\hline $30 \% \mathrm{WF}+70 \% \mathrm{BF}$ & $21.56 \pm 0.19$ & $5.87 \pm 0.14$ & $3.10 \pm 0.29$ & 18.94 \\
\hline $100 \% B F$ & $20.67 \pm 2.67$ & $5.38 \pm 0.15$ & $3.24 \pm 0.28$ & 16.60 \\
\hline
\end{tabular}

${ }^{*}$ Values are means \pm SD $(n \geq 5)$ 


\section{ART'TlE $Y$}

Ipplied Resseirlches in Teednicis, Technologies and Eductation

Journal of the Faculty of Technics and Technologies, Trakia University https://sites.google.com/a/trakia-uni.bg/artte/

From table 1 it becomes clear that the volume of the cookies significantly rises by adding barley flour to the recipe content. The cookies containing $100 \%$ wheat flour have got the least volume $(7.89 \pm 1.54 \mathrm{~cm} 3)$, and the cookies containing $70 \%$ wheat flour and $30 \%$ barley flour have got the most volume $(24.89 \pm 0.77 \mathrm{~cm} 3)$. These values show that when in the content of the cookies both wheat and barley flours are present, their volume decreases with the increase of barley flour. Cookies width proportionally increases with increasingly adding barley flour (except for cookies $100 \% \mathrm{BF}$ ), from $5.33 \pm 0.41 \mathrm{~cm}$ for control sample to $5.87 \pm 0.14 \mathrm{~cm}$ for cookies with $70 \%$ barley flour. Cookies thickness (height) decreased with the addition of barley flour (except for cookies $50 \% \mathrm{WF}+50 \% \mathrm{BF}$ ). Spread factor for the cookies is from 16.60 , for cookies $100 \% \mathrm{BF}$, to 50.76 for cookies $100 \% \mathrm{WF}$.

Table 2 shows data about colour determination of the cookies via CIE $L^{*} a^{*} b$ system.

Table 2. Results of colour determination*

\begin{tabular}{|c|c|c|c|c|}
\hline Type of cookies & $L$ & $a$ & $b$ & $\Delta E$ \\
\hline $100 \%$ WF & $68.32 \pm 3.66$ & $-2.65 \pm 0.58$ & $18.94 \pm 0.67$ & $18.94 \pm 0.67$ \\
\hline $70 \% W F+30 \% B F$ & $51.70 \pm 2.78$ & $7.78 \pm 1.12$ & $26.61 \pm 1.30$ & $27.82 \pm 1.75$ \\
\hline $50 \% W F+50 \% B F$ & $50.68 \pm 2.35$ & $6.05 \pm 0.80$ & $24.83 \pm 0.77$ & $26.61 \pm 1.30$ \\
\hline $30 \% W F+70 \% B F$ & $47.61 \pm 2.02$ & $4.09 \pm 1,02$ & $27.82 \pm 1.75$ & $24.83 \pm 0.77$ \\
\hline $100 \% B F$ & $45.70 \pm 2.06$ & $3.04 \pm 0.50$ & $24.65 \pm 0.88$ & $24.65 \pm 0.88$ \\
\hline
\end{tabular}

*Values are means \pm SD $(n \geq 5)$

$L^{*}$ - the values show the brightness of the colour. The more the values tend towards 0 , the blacker the colour of the studied object is. If the values for this parameter are closer to 100 , then the studied object's colour is white. From the research done we concluded that the lowest value for $L^{*}$ parameter have the cookies produced from $100 \%$ barley flour (45.70 \pm 2.06$)$. The highest value have got the cookies produced from $100 \%$ wheat flour (68.32 \pm 3.66$)$. It is clear that by decreasing the quantity of barley flour, the values for this parameter increase. By the values of $a^{*}$ parameter in the CIE $L^{*} a^{*} b^{*}$ system, the colour of the studied object can be determined as either red or green. If the values for this parameter are positive, it means that the colour of the studied object is green. When the values for this parameter are negative, the cookies are red in colour. From the table, we can see that the sample cookies produced from $100 \%$ wheat flour have got negative value $(-2.65 \pm 0.58)$. The cookies containing $70 \%$ wheat flour and $30 \%$ barley flour, have got the highest value $(7.78 \pm 1.12)$. When wheat and barley flour both take part in the content, decrease in the values of $a^{*}$ parameter is observed by increasing the quantity of barley flour. $b^{*}$ values show if a certain object of study is blue or yellow in colour. If the values are negative then we say the studied object is blue. If the values are positive it has yellow colour. From the table we can see that the sample cookies have got the lowest values for that parameter $(18.94 \pm 0.67)$ and the cookies produced from $30 \%$ wheat flour and $70 \%$ barley flour have got the highest values $-(27.82 \pm 1.75) . \Delta \mathrm{E}$ parameter shows the connection between human perception of the cookie colour and the total change in colour. From the data shown it is clear that all types of cookies fall into the category of cookies with big differences in visibility $(>6)$, i.e. the differences in the colour of the dough and the colour of the ready cookies can be detected by the human eye. Figure 2 presents top and bottom surfaces of the five cookie types with different proportion of white and barley flour. 


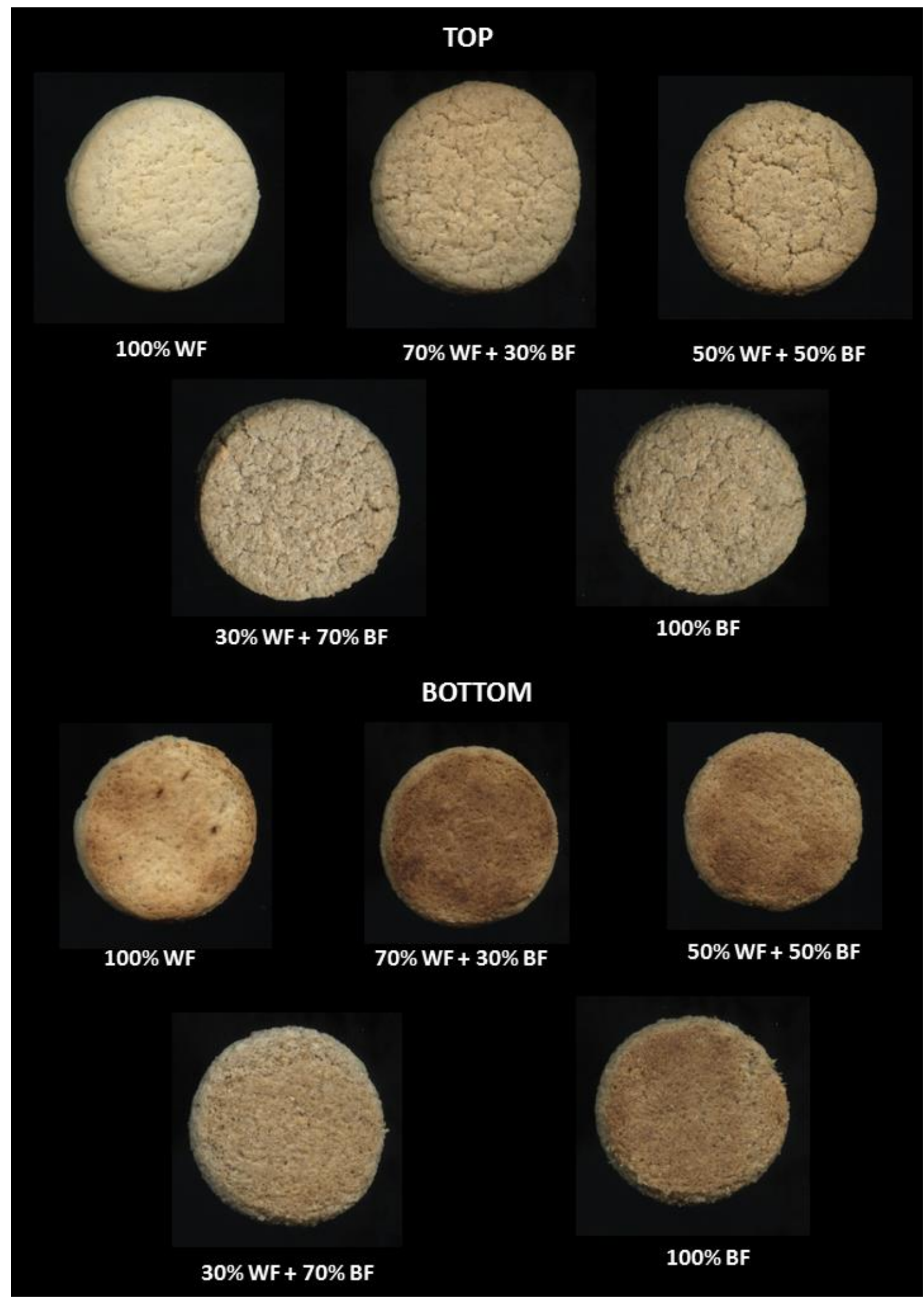

Figure 2. Top and bottom surfaces of the five cookie types with different proportion of white and barley flour

IRTTE Vol. 7, No. 2, 2019 ISSN 1314-8788 (print), ISSN 1314-8796 (online), doi: 10.15547/artte.2019.02.008 


\section{CONCLUSION}

From the analysis done we found that there is a real opportunity for cookie production with increased content of barley flour. These products can be defined as being functional. With increasing the quantity of barley flour into the content of the cookies, the baking loss increase as well as their width and thickness. The colour of the cookies becomes darker compared to the sample cookies. The difference between the colour of the dough and the ready product is perceptible for the human eye $(\Delta \mathrm{E}>6)$.

\section{ACKNOWLEDGMENTS}

The study was supported by contract of University of Ruse "Angel Kanchev", № BG05M2OP001-2.009-0011-C01, " Support for the development of human resources for research and innovation at the University of Ruse "Angel Kanchev". The project is funded with support from the Operational Program " Science and Education for Smart Growth 2014 2020" financed by the European Social Fund of the European Union.

\section{REFERENCES}

[1] AACC Method 10-50D. (2000). Baking Quality of Cookie Flour, Approved Method of the American Association of Cereal Chemists. $10^{\text {th }}$ ed. AACC, St. Paul.

[2] Cencic A. \& Chingwaru W. (2010). The Role of Funcitonal Foods, Nutraceuticals, and Food Supplements in Intestinal Health. Nutritients (2), (2010), pp. 611-625.

[3] Evans E.J. (2001). Cereal production methods. In: Cereal processing technology, Owens G., Woodhead Publishing Limited, England, (2001), pp. 7-26.

[4] Jukić, M., Lukinac J., Mastanjević K., Koceva Komlenić D., Martinović S., Šušak A. \& Nakov G. (2018). Quality evaluation of cookies produced from wheat flour and brewer's malted barley flour. Proceedings of the 7th International Specialized Scientific and Practical Conference, (2018), pp. 74-76.

[5] Keser M. (2016). Utjecaj Dodatka Jabučnog Tropa na Kvalitativne Parametre Kruha Tijekom Pečenja. Prehrambeno-tehnološki fakultet Osijek, Specijalistički rad, (2016).

[6] Koehler P. \& Weiser H. (2013). Chemistry of Cereal Grains. In: Handbook on Sourdough Biotechnology. Gobbetti, M., Gänzle, M. Springer, (2013).

[7] Nakov G., Stamatovska V., Ivanova N., Damyanova S., Godjevargova Tz. \& Koceva Komlenić D. (2018). Psychochemical characteristics of functional biscuits and In vivo determination of glucose in blood after consumption of functional biscuits. Journal of Hygienic Engineering and Desing, 22, (2018), pp. 25-32.

[8] Noorfarahzilah M., Lee J. S., Sharifudin M. S., Moht Fadzelly A. B. \& Hasmadi M. (2014). International Food Research Jourinal, 23, (6), (2014), pp. 2061-2074.

[9] Sulieman E. A., Mohammed A. O. \& Elkhalifa E. A. (2008). Evaluation of the chemical and sensory characteristics of biscuits supplemented with soybean flour. Gezira Journal of Agricultural Science, Vol. 6 (1), (2008), pp. 97-107.

[10] Ullrich E. S., Baik K. B., Quinde-Axtell Z. \& Nair S. (2008). Barley for food: traits and improvements. Proceedings of the 10th International Barley Genetics Symposium, Alexandria, Egypt, (2008), pp. 563-575. 